\title{
CHARACTERIZING GAS PERMEABILITY AND PORE PROPERTIES OF CZECH GRANITIC ROCKS
}

\author{
Pavel KONEČNÝ ${ }^{1)}$ * and Alena KOŽUŠNÍKOVÁ ${ }^{2)}$ \\ ${ }^{1)}$ Institute of Geonics, Academy of Sciences of the Czech Republic, Studentská 1768, 70800 Ostrava-Poruba, Czech Republic \\ ${ }^{2)}$ Institute of Clean Technologies for Mining and Utilization of Raw Materials for Energy Use, \\ Institute of Geonics AS CR, v. v. i., Ostrava, Czech Republic \\ *Corresponding author's e-mail: konecpa@ugn.cas.cz
}

\begin{tabular}{l} 
ARTICLE INFO \\
\hline Article history: \\
Received 3 December 2015 \\
Accepted 24 April 2016 \\
Available online 10 May 2016 \\
\hline
\end{tabular}

Keywords:

Granite

Permeability

Pore properties

Triaxial state of stress

\begin{abstract}
The main objective of this paper is to clarify the permeability of Czech granitic rocks to describe the filtration properties and their changes due to hydrostatic pressure. For this purpose, various petrographic types of granitic rocks from five geological regions of important intrusions of Variscan granitoids were selected. In addition to permeability, rock properties that characterize the porous system (total porosity, water absorptive capacity, and porosity determined by mercury porosimetry) were measured.

Although the tested rock samples were intact, the permeability of granitic rocks can vary by more than four orders of magnitude depending on the sample location. The range of values varies from $10^{-16}$ to $10^{-20} \mathrm{~m}^{2}$ for a confining pressure of $5 \mathrm{MPa}$. The increase in hydrostatic pressure causes an additional noticeable decrease in the permeability.

The obtained results can play a crucial role in solving the coupled thermo-hydro-mechanical (THM) processes and individual problems of the deposition of nuclear waste in the geological environment.
\end{abstract}

\section{INTRODUCTION}

The deposition of nuclear waste in suitable underground rock formations is one of the ways of removing radioactive waste from the biosphere.

The sources of nuclear waste in the Czech Republic are nuclear power plants, research, other radionuclide users, and waste from decommissioning of radionuclide laboratories. The long-term stability of excavations in crystalline rock massifs together with the low permeability of these rocks is an advantage over other rock types with respect to retrievability. Since solution and transport in moving groundwater is the primary pathway by which radionuclides can move from the underground to the biosphere, rock types and geological conditions where groundwater flow is very slow (low permeability rocks) were recognized as a suitable environment (Fairhurst, 2004).

In the Czech Republic there are two repositories, Richard and Bratrství, that can handle low level waste (LLW) and intermediate-level waste (ILW). The repository for high-level waste (HLW) produced by nuclear power engineering facilities was constructed by the nuclear power plant operator in Dukovany (OECD Publications, 1999). However, there are still both national and international projects dealing with the concept of deep geological storage of LLW, ILW, and particularly HLW in crystalline host rocks (Tsang et al., 2005).
In the deposition of nuclear waste in a geologic formation, coupled thermo-hydro-mechanical (THM) processes are taken into account. When considering HLW, the permeability of the rock matrix and fractures are studied (Neuman, 2008). This study focuses on the bulk transport properties of rocks, which are one factor that influences the fluid flow in the Earth's crust (Mitchell and Faulkner, 2012). However, if the fracture network is present in the rock massif, the fracture permeability is the most important for modelling of long-term flow (Koike et al., 2015).

The objective of this paper is to clarify the permeability of Czech granitic rocks and its changes due to hydrostatic pressure.

\section{MATERIAL AND METHODS}

\subsection{TESTED MATERIAL}

The most important granitic rocks in the Czech Republic occur mainly as Variscan intrusions (the absolute age of these intrusions is 340-250 Ma, measured by radiometry) (Chlupáč et al., 2011). Older granitic rocks are usually influenced by Variscan orogeny.

Samples of compact granitic rocks were taken from five geological regions of important intrusions of Variscan granitoids in the Czech Republic (Fig. 1):

Two samples, nos. 11776 (Fig. 2) and 5337, were taken from the Ruprechtice quarry, a part of Krkonoše-Jizera pluton (KJP). The samples were 


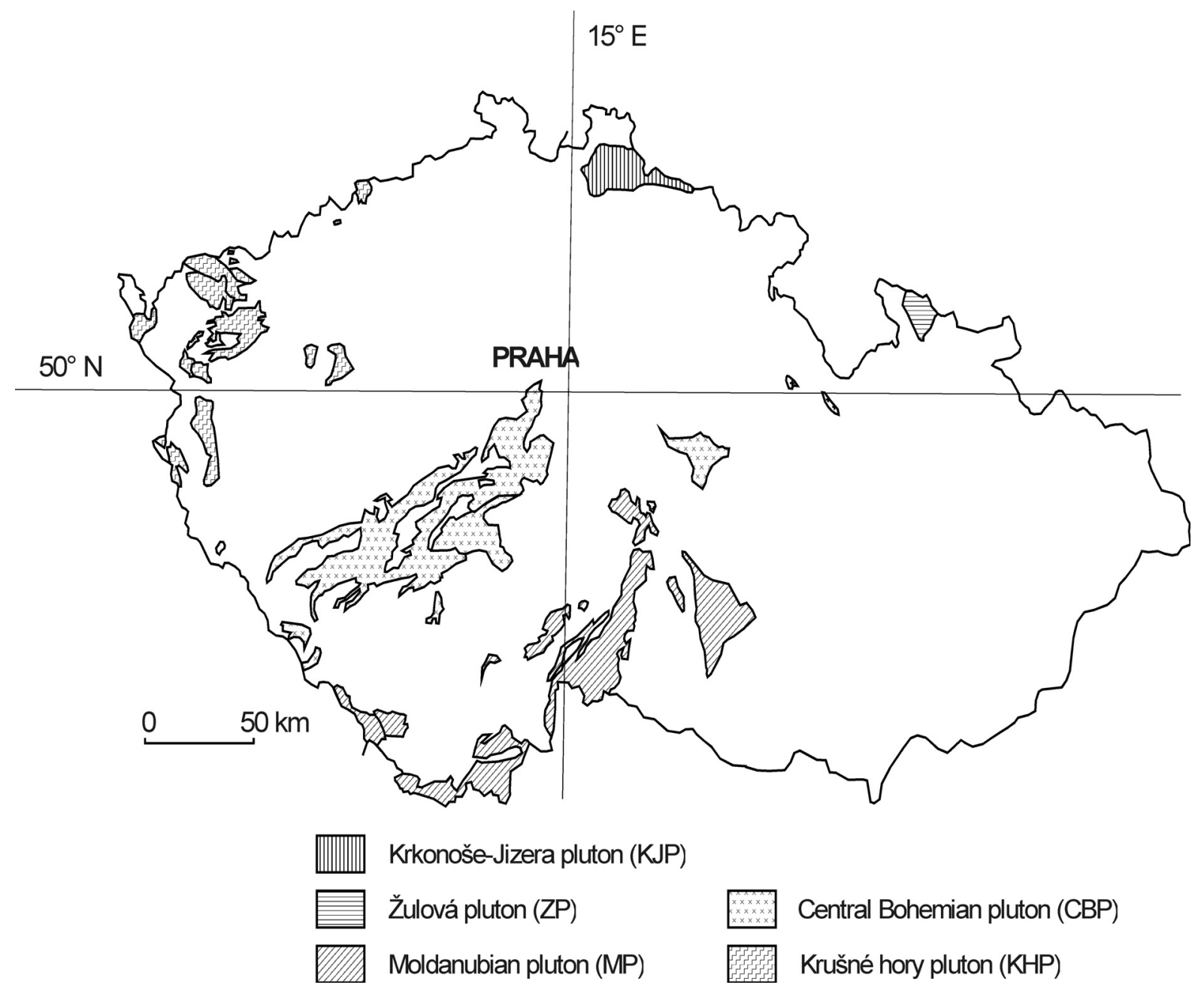

Fig. 1 Map of Variscan granitoids in the Czech Republic (modified from Chlupáč et al., 2011).

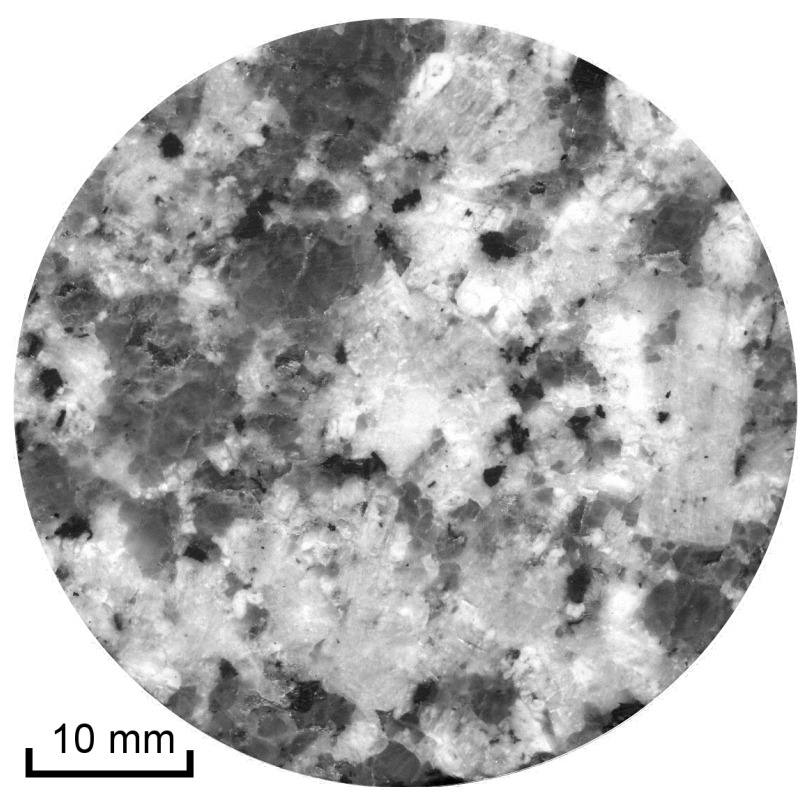

Fig. 2 Coarse-grained texture and massive structure of granite sample no. 11776 from KrkonošeJizera pluton.

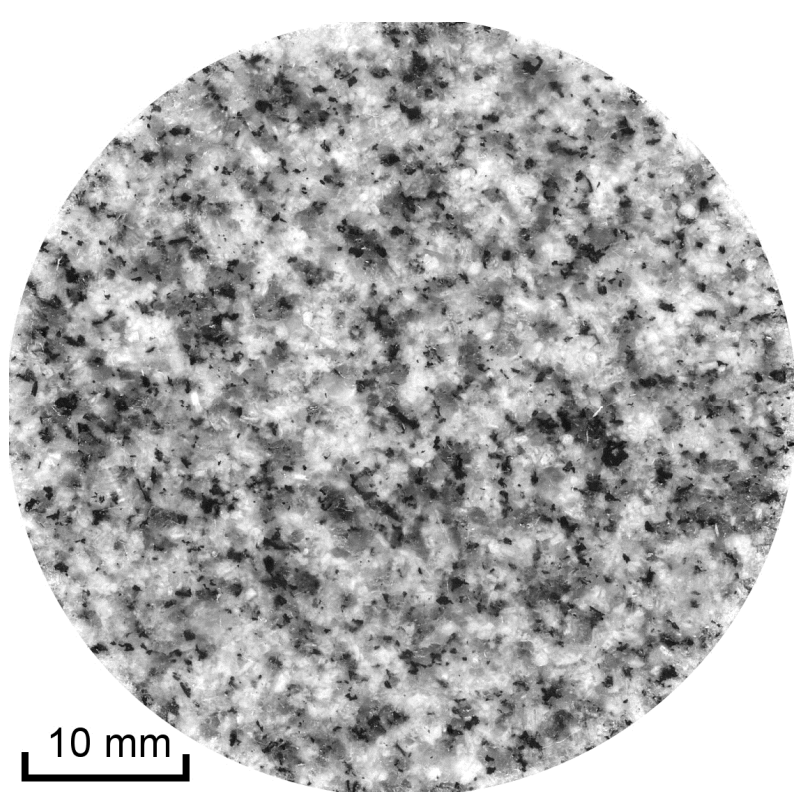

Fig. 3 Medium-grained texture and massive structure of granite sample no. 10109 from Žulová pluton. 


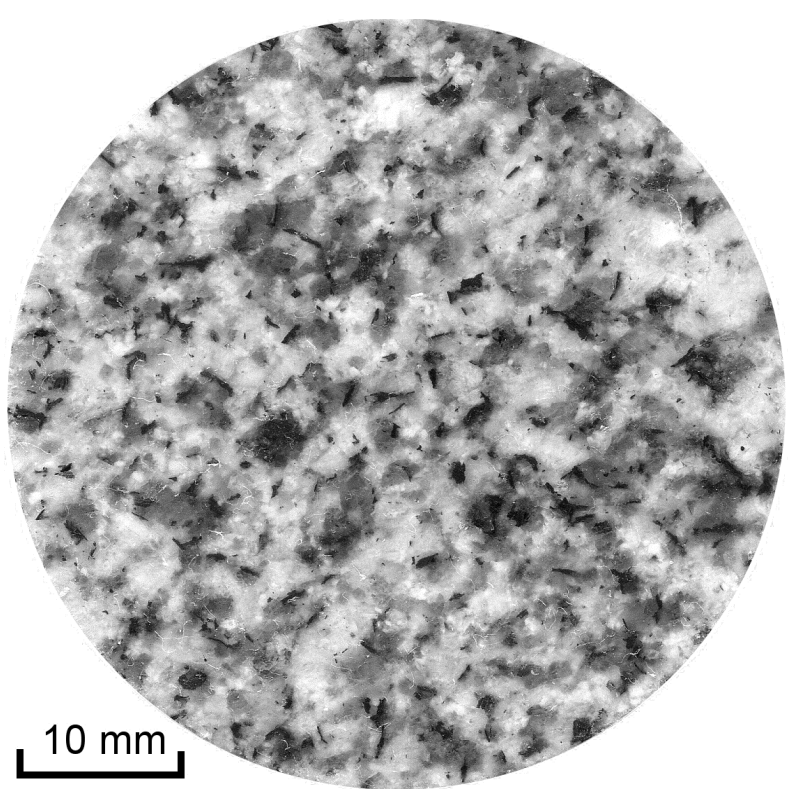

Fig. 4 Medium-grained texture and massive structure of granite sample no. 13379 from Moldanubian pluton.

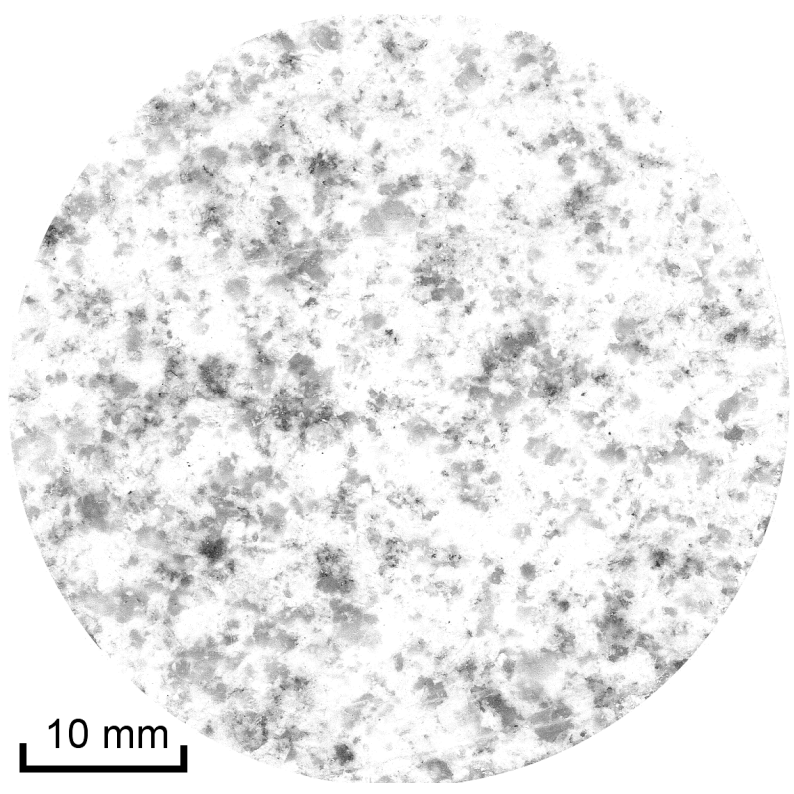

Fig. 6 Small-grained texture and massive structure of granite sample no. 13753 from Krušné hory pluton.

porphyric coarse-grained biotite granite with the occurrence of feldspar phenocrysts up to $3 \mathrm{~cm}$ in size and directionless structure.

Two samples, nos. 10109 (Fig. 3) and 9164, were taken from the Nový lom quarry, and no. 4073 was taken from Erlich quarry, a part of Žulová pluton (ZP). Petrographically identical samples of so-called "Silasia granite" were medium-grained biotite granite with allotriomorphic grains (quartz, feldspar) with the exception of biotite (hypidiomorphic) and directionless structure.

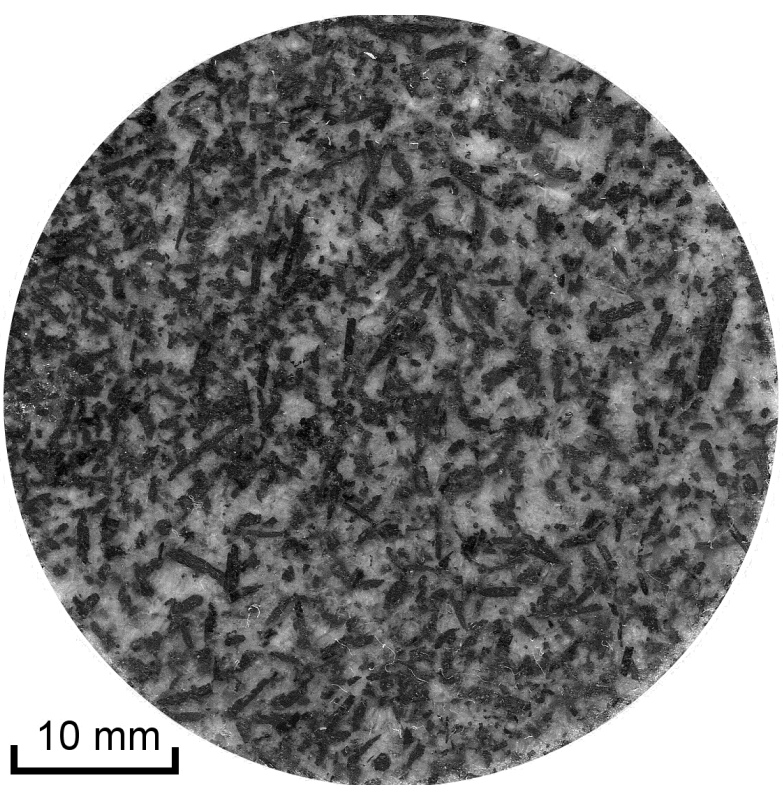

Fig. 5 Small-grained texture and massive structure of sample no. 4083 from Central Bohemian pluton.

Two samples, nos.13379 (Fig. 4) and 13380, were taken from Mrákotín quarry, a part of Moldanubian pluton (MP). The samples were medium-to-small-grained biotite-muscovite (no. 13380), and biotite (no.13789) granite with the occurrence of large grains (up to $10 \mathrm{~mm}$ ) of microcline (no. 13380) and directionless structure.

Three samples, nos. 4083, 4573, and 4575, were taken during the building of the Prríbram gas reservoir in an ancient underground mine, a part of Central Bohemian pluton (CBP).

Sample no. 4083 (Fig. 5) was small-grained biotite-pyroxene-amphibole diorite with directionless structure. Sample no. 4573 was medium-grained biotite-amphibole granodiorite with directionless structure. Sample no. 4575 was porphyritic mediumgrained biotite-amphibole granodiorite with the occurrence of feldspar phenocrysts up to $1.5 \mathrm{~cm}$ in size and directionless structure.

Three samples were taken from Krušné hory pluton (KHP) (Žůrek et al., 2008). Samples nos. 13750 and 13753 were taken from the open pit mine in Krásno and sample no.13827 from the ancient underground mine of Jeroným in Čistá. Sample no. 13750 was fine-grained aplitic granite with altered feldspars and directionless structure. Sample no. 13753 (Fig. 6) was small-grained granite with altered feldspars, directionless structure, and sporadic occurrence of muscovite. Sample no. 13827 was medium-grained biotite granite with directionless structure.

Petrographic analysis and classification of the tested samples were carried out according to Dudek et al. (1962), Krist and Krivý (1985), MacKenzie et al. (1997) and Winter (2010). 


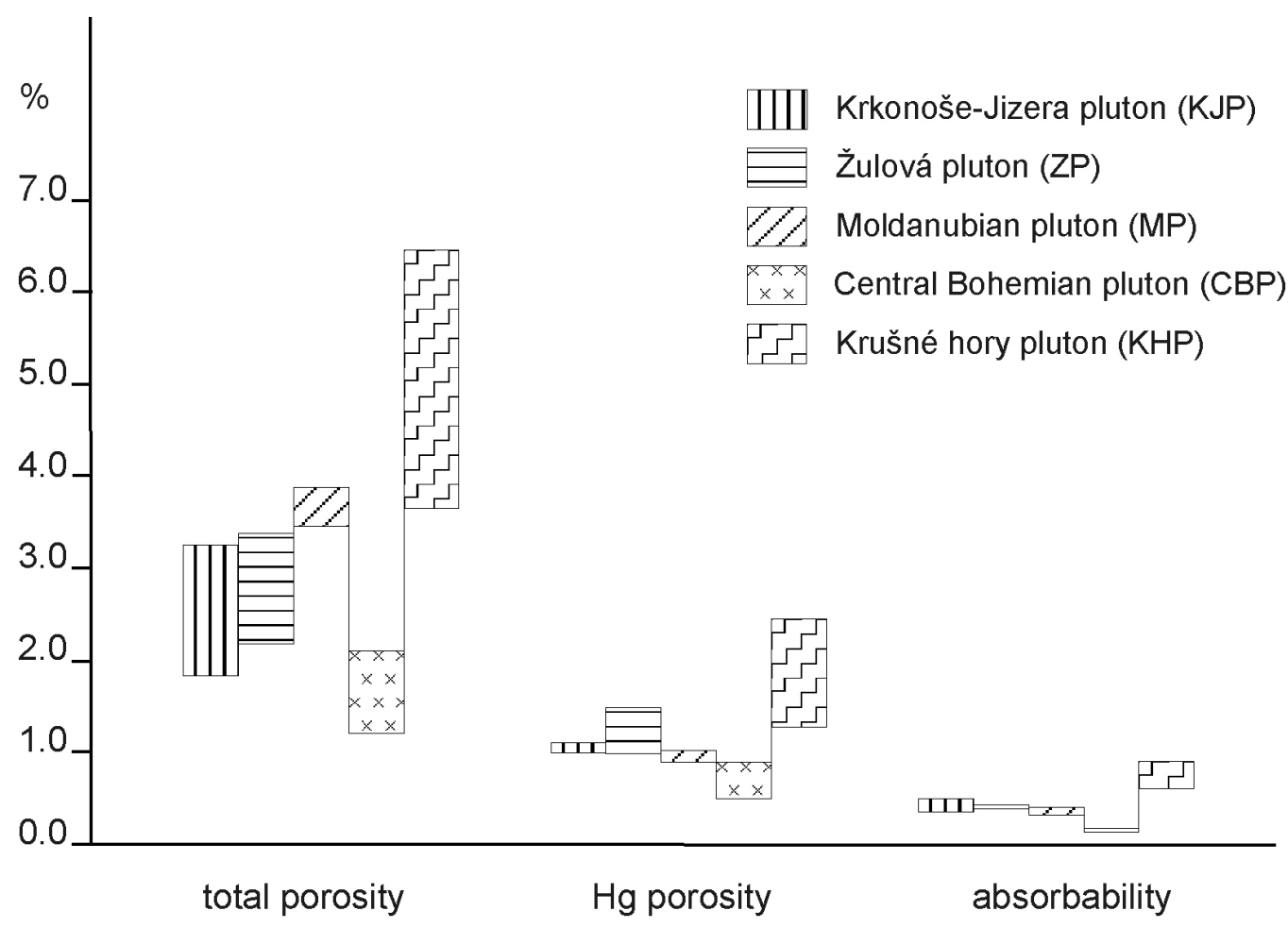

Fig. 7 Total porosity, Hg porosity, and water absorbability of tested samples for selected regions. The height of the filled column represents the range of values from minimum to maximum.

\subsection{EXPERIMENTAL METHOD}

The permeability measurement is based on the gradual increase of the hydrostatic pressure of the hydraulic oil in the KTK 100 triaxial cell (produced by the company Unipress, Poland, and modified for gas passages). The tested specimen of cylindrical shape with a diameter of $48 \mathrm{~mm}$ and a slenderness ratio of 2:1 (height to diameter) is clamped in the jaws of a Zwick 1494 mechanical press with a maximum force of $600 \mathrm{kN}$, controlled by computer. The confining pressure induced by hydraulic oil is gradually increased from $5 \mathrm{MPa}$ with a step of $5 \mathrm{MPa}$ up to a maximum of $30 \mathrm{MPa}$, and the axial stress has the same value as the confining pressure so that in the test specimen a hydrostatic three-dimensional stress status is induced $\left(\sigma_{1} \approx \sigma_{2}=\sigma_{3}\right)$ (Kožušníková and Konečný, 2011). The increasing hydrostatic pressure in laboratory conditions simulates the in situ situation. From in situ stress measurements (Staš at al., 2011), triaxial laboratory testing up to $30 \mathrm{MPa}$ corresponds to the depth up to $1000 \mathrm{~m}$.

The pressure of the gas medium was regulated from the gas pressure vessel by a control valve so that during the whole period of the experiment the pressure was kept at $3 \mathrm{MPa}$. Nitrogen was used as a gas medium for all experiments. At selected hydrostatic pressures, the volume flow of nitrogen was measured and permeability was assessed using Darcy's law (ASTM Standards, 1990).

The measurement of the volume of gas flow per unit time was realized by flowmeters up to $0.006 \mathrm{~m}^{3} / \mathrm{s}$ or by measuring cylinder, from where it suppressed water whose volume corresponded to the volume of gas flow (Konečný and Kožušníková, 2011).
The methodology for measuring permeability during an increase of hydrostatic pressure was developed at the Institute of Geonics in the Laboratory of Petrology and the Physical Properties of Rocks (Konečný and Kožušníková, 1996; Kožušníková and Konečný, 2011).

\section{RESULTS AND DISCUSSION}

Total porosity, water absorptive capacity, and porosity determined by mercury porosimetry were measured as the basic porous properties (David et al., 1999) of the tested samples (Fig. 7).

Total porosity was assessed from the bulk density of rock $\left(\rho_{\mathrm{d}}\right)$ determined on dried cylindrical specimens and grain density $\left(\rho_{\mathrm{s}}\right)$ (Ulusay and Hudson, 2007).

The water absorptive capacity of the sample was determined from the mass of the dry specimen and from the mass of the same specimen saturated by water at atmospheric pressure for 48 hours (Ulusay and Hudson, 2007; Konečný et al., 1999).

The $\mathrm{Hg}$ porosity was determined on specimens of $0.01 \times 0.01 \times 0.02 \mathrm{~m}$ by an Autopore 9500 from Micromeritics. A mercury porosimeter using $\mathrm{Hg}$ penetration into the sample allowed the size and distribution of macro- and mesopores to be measured. The determined pore sizes ranged from 0.0055 to $360 \mu \mathrm{m}$. The measuring was performed in two successive regimes: at low pressure from 0 to $345 \mathrm{kPa}$ and at high pressure from 0.1 to $228 \mathrm{MPa}$. The final cumulative curves of porosity were categorized into three pore radii: smaller than $50 \mathrm{~nm}$, from 50 to $500 \mathrm{~nm}$, and greater than $500 \mathrm{~nm}$. The results of $\mathrm{Hg}$ porosity and the pore type distributions are shown in Figures 7 and 8, respectively. 


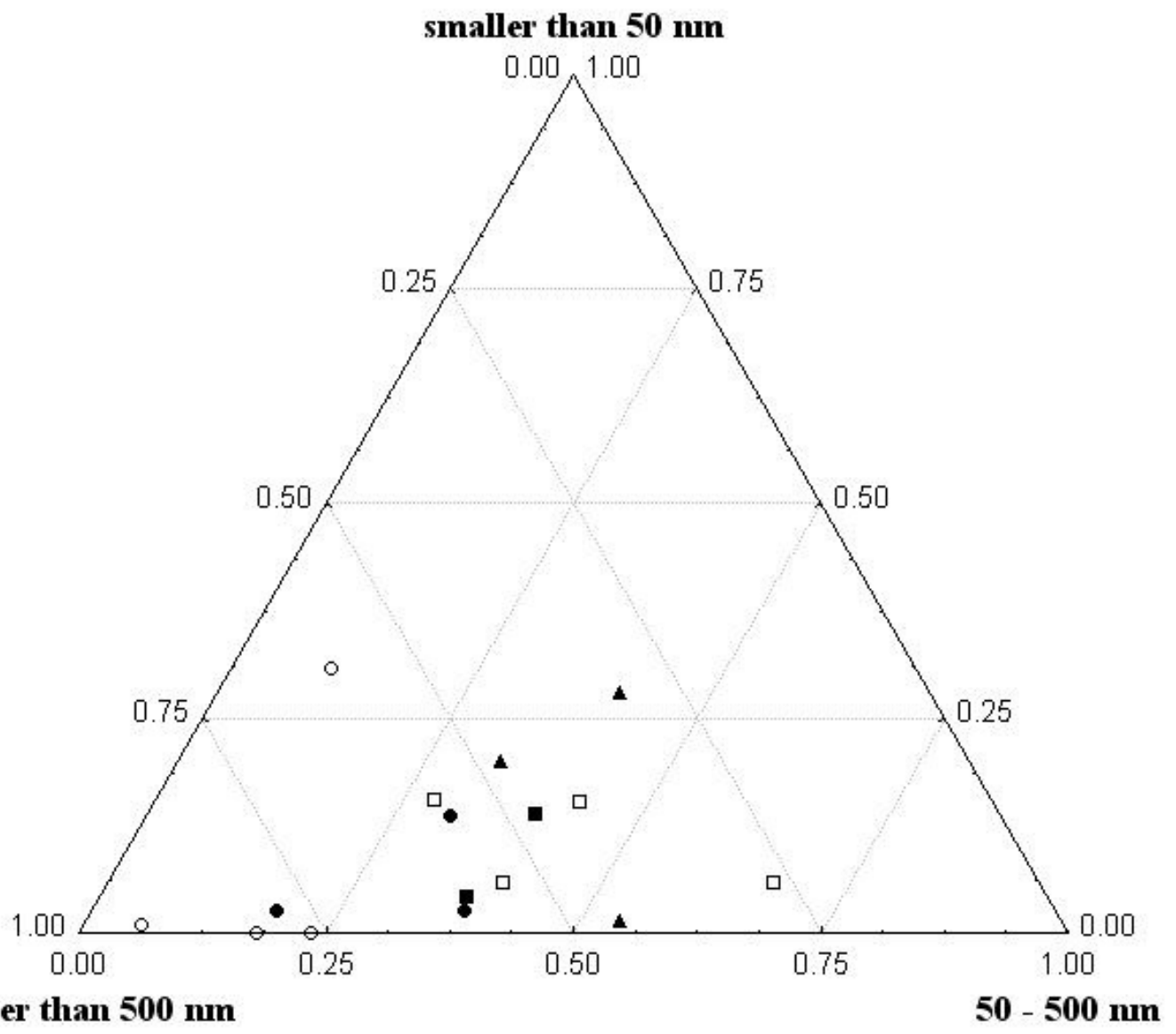

greater than $500 \mathrm{~nm}$

Fig. 8 Distribution of pores in tested samples (• KJP, $\Delta \mathrm{ZP}, \boldsymbol{\square} \mathrm{MP}, \circ \mathrm{CBP}, \square \mathrm{KHP})$.

The differences in porosity between the granite samples and used measurement methods are clearly shown in Figure 7. The relatively large volumes of pores determined by total porosity are influenced by the presence of isolated pores. On the other hand the water absorptive capacity is measured in cylindrical specimens and covers only connected pores.

It is apparent that the permeability measured for the same confining pressure differs both among the specimens from the same localities and among specimens from different regions. Although the differences in permeability of similar granitic rocks from one region generally do not exceed one order of magnitude, the differences in permeability among specimens from different regions could differ by several orders of magnitude (Fig. 9). The highest permeability for $5 \mathrm{MPa}$ of confining pressure is shown by the specimens from Krkonoše Jizera pluton (more than $10^{-17} \mathrm{~m}^{2}$ ), whereas specimens from the Central Bohemian pluton have a permeability of around $10^{-19} \mathrm{~m}^{2}$.

With increases in confining pressure, all the tested specimens clearly show decreases in permeability (Fig. 9). However, the decrease in permeability does not exceed one order of magnitude when the hydrostatic pressure increases from 5 to 30 MPa.

Comparing the effects of porosity determined by measurement of total porosity (Fig. 10), Hg porosity
(Fig. 11), or water absorbability (Fig. 12) on permeability, we can see that increases in the value of porosity apparently cause increases in permeability. Figures 10-12 show a correlation between the total porosity, $\mathrm{Hg}$ porosity, water absorbability, and permeability for specimens from the four regions $\mathrm{ZP}$, $\mathrm{MP}, \mathrm{CBP}$, and KHP.

It is also visible in Figures 10-12 that the measured values of specimens from KJP, which have relatively high permeability, deviate from those of the rest of the specimens.

The porosity is similar for the specimens from KJP and ZP (Fig. 7), while the permeability is almost two orders of magnitude higher for specimens from KJP. This difference is possibly caused by the direction of microfractures and the distribution of pores (Fig. 8). This conclusion agrees with the different values of ultrasonic wave velocity and $\mathrm{Hg}$ porosity measurements. The specimens from KJP have an obviously higher proportion of pores greater than $500 \mathrm{~nm}$ compared to specimens from ZP (Fig. 8). The longitudinal ultrasonic wave velocity of specimens from KJP ranged from 2940 to $2960 \mathrm{~m} \cdot \mathrm{s}^{-1}$, while that of specimens from ZP ranged from 4000 to $5100 \mathrm{~m} \cdot \mathrm{s}^{-1}$.

\section{CONCLUSIONS}

Through the experimental permeability measurements of the Czech granitic rocks, all the 


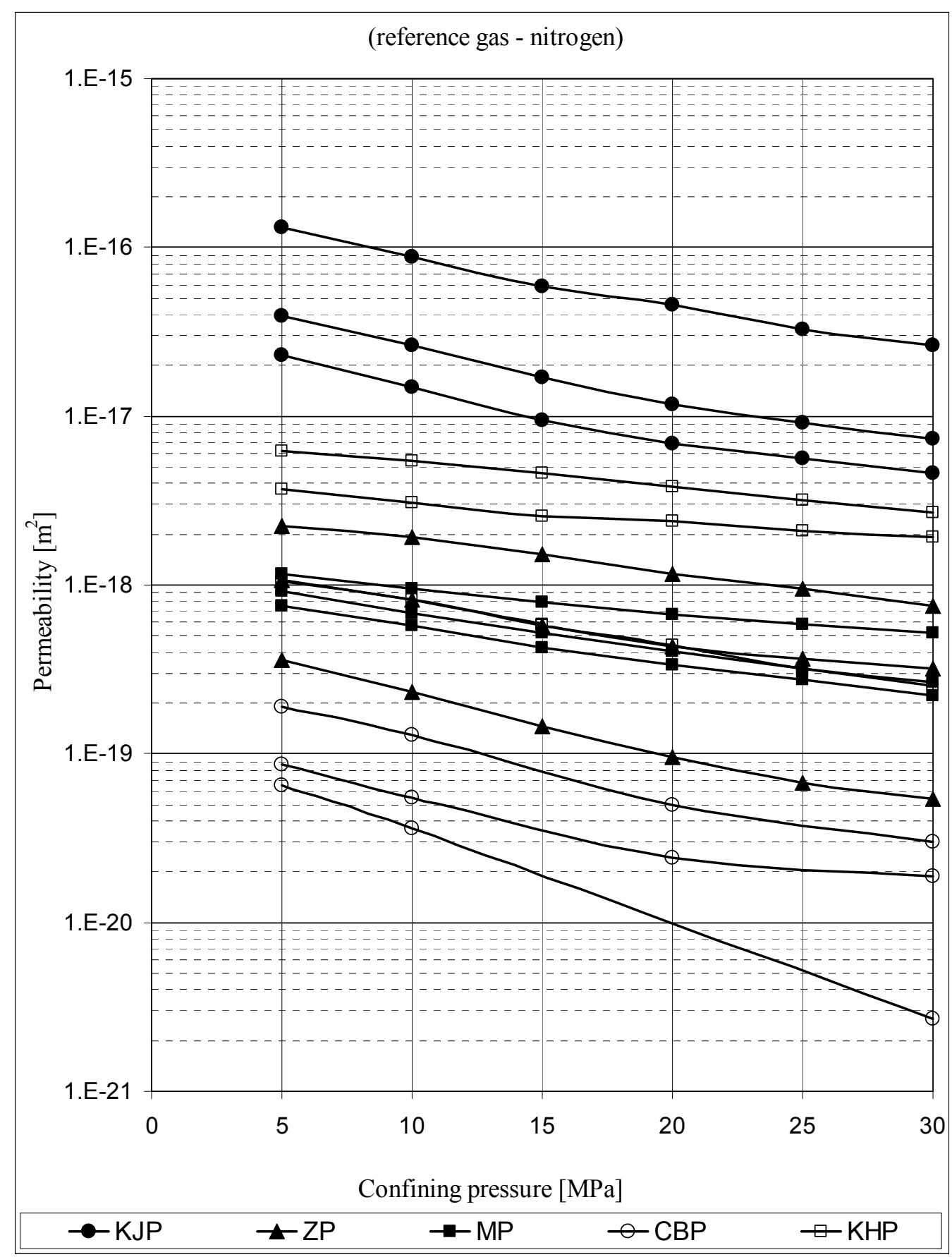

Fig. 9 Change in permeability with increasing confining pressure.

tested specimens are classified as "infinitesimally permeable" rocks (Jetel, 1982). Although the rock samples are intact, the permeability of granitic rocks can vary by more than four orders of magnitude depending on the sample location. The range of the values varies from $10^{-16}$ to $10^{-20} \mathrm{~m}^{2}$ for a confining pressure of $5 \mathrm{MPa}$.

Moreover, the increase in hydrostatic pressure causes an additional noticeable decrease in the permeability of all tested specimens.

The porous medium of the specimen was quantified by the different measurements of porosity. Although the permeability can be correlated with the rock porosity, the permeability is also influenced by gas transport properties such as the orientation and tortuosity of pores and micro-cracking.

There are noticeable differences of more than four orders of magnitude between the permeabilities of the granitoids depending on the region. This fact must be taken into account when considering very long-term THM processes. The tectonic situation is the most important for the permeability of rock massif, but the bulk transport properties of rock matrix must also be studied individually for each geological site.

\section{ACKNOWLEDGEMENTS}

The presented work has been supported financially by the Academy of Sciences of the Czech Republic (project RVO: 68145535) and by the Grant 


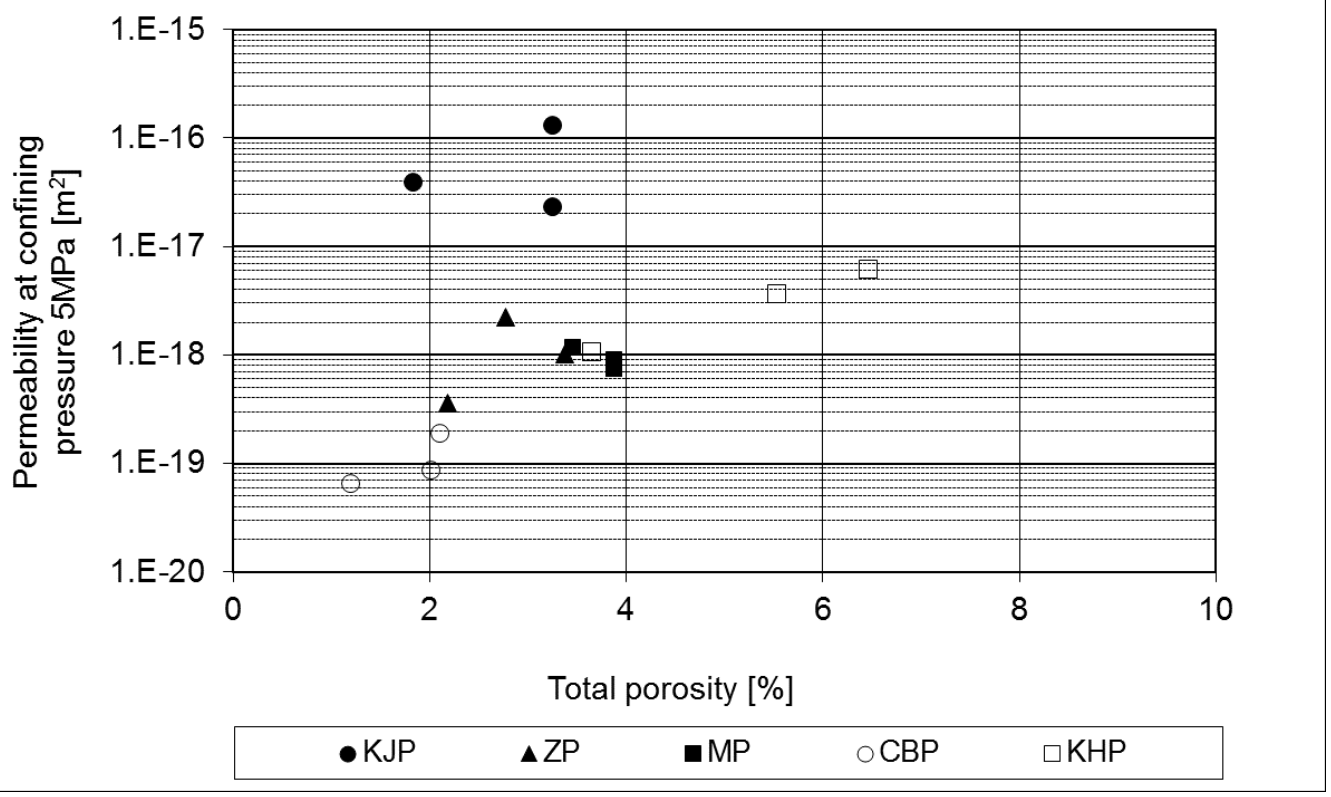

Fig. 10 Effect of total porosity on permeability at a confining pressure of $5 \mathrm{MPa}$.

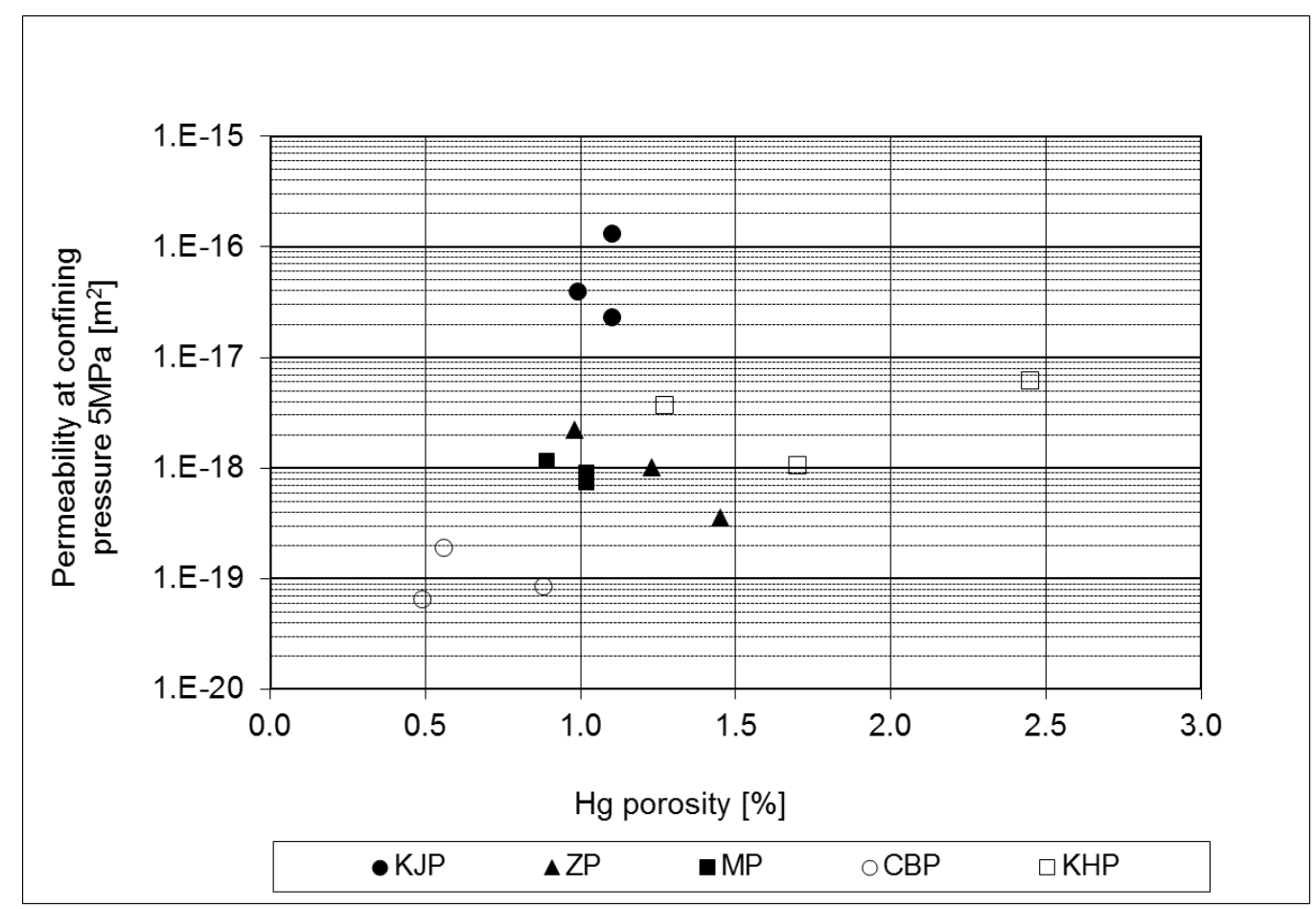

Fig. 11 Effect of $\mathrm{Hg}$ porosity on permeability at a confining pressure of $5 \mathrm{MPa}$.

Agency of the Czech Republic (project no. GA105/09/0089) and has been realized in connection with a project of the Institute of Clean Technologies for Mining and Utilization of Raw Materials for Energy Use [reg. no. CZ.1.05/2.1.00/03.0082 (LO1406)] supported by the Research and Development for Innovations Operational Programme financed by the Structural Funds of European Union and from the state budget of the Czech Republic.

\section{REFERENCES}

ASTM Standards, D 4525: 1990, Standard test method for permeability of rocks by flowing air. Annual Book of ASTM Standards, 04.08, 825-828.

Chlupáč, I., Brzobohatý, R., Kovanda, J. and Stráník, Z.: 2011, Geological history of the Czech Republic. Academia, Praha, (in Czech).

David, C., Menendéz, M. and Darot, M.: 1999, Influence of stress-induced and thermal cracking on physical properties and microstructure of La Peyratte granite. 




Fig. 12 Effect of water absorbability on permeability at a confining pressure of $5 \mathrm{MPa}$.

Int. J. Rock Mech. Min. Sci., 36, 433-448.

DOI: 10.1016/S0148-9062(99)00010-8

Dudek, A., Fediuk, F. and Palivcová, M.: 1962, Petrographic tables. ČSAV, Praha, (in Czech).

Fairhurst, C.: 2004, Nuclear waste disposal and rock mechanics: contributions of the Underground Research Laboratory (URL), Pinawa, Manitoba, Canada. Int. J. Rock Mech. Min. Sci., 41, 1221-1227. DOI:10.1016/j.jirmms.2004.09.001

Jetel, J.: 1982, Determination of hydraulic parameters of rocks by hydrodynamic tests in boreholes. ÚÚG in Academia, Praha, (in Czech).

Koike, K., Kubo, T., Liu, C., Masoud, A.A., Amano, K., Kurihara, A., Matsuoka, T. and Lanyon, B.: 2015, 3D geostatistical modeling of fracture system in a granitic massif to characterize hydraulic properties and fracture distribution. Tectonophysics, 660, 1-16. DOI:10.1016/j.tecto.2015.06.008

Konečný, P. Jr. and Kožušníková, A.: 1996, Measurement of gas permeability of coal and clastic sedimentary rocks under triaxial stress conditions. In: Coalbed Methane and Coal Geology, Gayer, R., Harris, I., editors. London: Geological Society Special Publication, 109, 227-229.

Konečný, P. Jr. and Kožušníková, A.: 2011, Influence of stress on the permeability of coal and sedimentary rocks of the Upper Silesian basin. Int. J. Rock Mech. Min. Sci., 48, 347-352. DOI: 10.1016/j.ijrmms.2010.11.017

Konečný, P. Jr., Kožušníková, A. and Martinec, P.:1999, Rock mass as a porous medium: Gas filtration ability in triaxial state of stress. In: Proc. 9th. Int. Congr. Rock Mechanics, Paris, 761-764.

Kožušníková, A. and Konečný, P.: 2011, Influence of temperature on the permeability of rocks. Géotechnique, 61 (12), 1081-1085.

DOI: 10.1680/geot.8.T.034

Krist, E. and Krivý, M.: 1985, Petrology. ALFA, Bratislava, SNTL, Praha, (in Slovak).
OECD Publications: 1999, Low-Level Radioactive Waste Repositories: An Analysis of Costs. Paris.

MacKenzie, W.S., Donaldson, C.H. and Guilford, C.: 1997, Atlas of igneous rocks and their textures. Harlow, Essex , Addison Wesley Longman Limited.

Mitchell, T.M. and Faulkner, D.R.: 2012, Towards quantifying the matrix permeability of fault damage zones in low porosity rocks. Earth Planet. Sci., Lett., 339-340, 24-31. DOI:10.1016/j.epsl.2012.05.014

Neuman, S.P.: 2008, Multiscale relationships between fracture length, aperture, density and permeability. Geophys. Res. Lett., 35, L22402.

DOI: 10.1029/2008GL035622

Staš, L., Knejzlík, J., Palla, L., Souček, K. and Waclawik, P.: 2011, Measurement of stress changes using compact conical -ended borehole monitoring. Geotech. Test. J., 34 (6), 685-693.

DOI: $10.1520 /$ GTJ102794

Tsang, C.F., Jing, L., Stephansson, O. and Kautsky, F.: 2005, The DECOVALEX III project: A summary of activities and lessons learned. Int. J. Rock Mech. Min. Sci., 42, 593-610. DOI: 10.1016/j.ijrmms.2005.03.003

Ulusay, R. and Hudson, J.A.: 2007, The complete ISRM suggested methods for rock characterization, testing and monitoring: 1974-2006. Ankara.

Winter, J.D.: 2010, Principles of igneous and metamorphic petrology. New York, Prentice Hall.

Žůrek, P., Koř́inek, R., Kaláb, Z., Hrubešová, E., Knejzlík, J., Daněk, T., Kukutsch, R., Michalčík, P., Lednická, M. and Rambouský, Z: 2008, Historical Jeroným Mine in Čistá. Monografie VŠB-TU Ostrava, ÚGN AV ČR, Ostrava, (in Czech). 